\title{
Effect of cover crops and nitrogen rates on sprinkler irrigated wheat in low altitude cerrado ${ }^{1}$
}

\author{
Michelle Traete Sabundjian"2*, Orivaldo Arf ${ }^{3}$, Flávio Hiroshi Kaneko ${ }^{4}$, Flávia Constantino Meirelles ${ }^{5}$, \\ Marcelo Valentini Arfo, Vagner do Nascimento ${ }^{2}$
}

10.1590/0034-737X201663030017

\begin{abstract}
Wheat production in the Brazilian cerrado faces major challenges, especially for not being a traditionally wheat region and the occurrence of hot and dry winters. The objective of this study was to evaluate the residual effect of the previous crops corn and Urochloa ruziziensis (R. Germ \& Evrard), in single cropping and intercropping, with and without seed inoculation with Azospirillum brasilense and topdress nitrogen fertilization $(\mathrm{N})$, on the development and yield of wheat. The experiment was conducted in Selvíria, MS, in 2011/12. The experiment was arranged in an $8 \times 4$ factorial randomized block design, with four replications. The treatments consisted of a combination of crop residues (corn, Urochloa ruziziensis and Azospirillum brasilense) and topdress $\mathrm{N}$ rates $\left(0,30,60\right.$ and $\left.90 \mathrm{~kg} \mathrm{ha}^{-1}\right)$ applied to wheat. The following evaluations were carried out: the amount of residual vegetation cover, agronomic characteristics, yield components and yield of wheat. There were positive effects of the previous crops on the yield of the succeeding wheat crop, and the intercropping corn x Urochloa ruziziensis, with or without inoculation, was an excellent management choice; increasing $\mathrm{N}$ rates in topdress up to $90 \mathrm{~kg} \mathrm{ha}^{-1}$ increased the yield of irrigated wheat, depending on the previous crop.
\end{abstract}

Key words: Triticum aestivum L.; no till; Zea mays L.; Urochloa ruziziensis R. Germ \& Evrard; intercropping; Azospirillum brasilense.

\section{RESUMO}

\section{Efeito de coberturas vegetais e doses de nitrogênio em cobertura no trigo irrigado por aspersão em cerrado de baixa altitude}

A produção de trigo no cerrado brasileiro enfrenta grandes desafios, principalmente por não ser a região tradicionalmente tritícola e pela ocorrência de inverno quente e seco. Assim, o objetivo deste trabalho foi avaliar o efeito residual das culturas antecessoras, milho e Urochloa ruziziensis (R. Germ \& Evrard), em cultivo exclusivo e em consórcio entre ambas, na presença e ausência da inoculação de sementes com Azospirillum brasilense e adubação nitrogenada $(\mathrm{N})$ em cobertura, no desenvolvimento e na produtividade do trigo. O experimento foi desenvolvido em Selvíria, MS, em 2011/ 12. O delineamento experimental foi o de blocos ao acaso, disposto em esquema fatorial $8 \times 4$, com quatro repetições, cujos tratamentos foram constituídos pela combinação de restos culturais (associações de milho, Urochloa ruziziensis e Azospirillum brasilense) e doses de N (0,30,60 e $\left.90 \mathrm{~kg} \mathrm{ha}^{-1}\right)$ em cobertura, no trigo. Realizaram-se as seguintes

Submitted on September $25^{\text {th }}, 2014$ and accepted on February $1^{\text {st }}, 2016$

${ }^{1}$ This work is part of the first author master's thesis.

${ }^{2}$ Universidade Estadual Paulista “Júlio de Mesquita Filho”, Faculdade de Engenharia de Ilha Solteira, Ilha Solteira, São Paulo, Brasil. michelletraete@hotmail.com

${ }^{3}$ Universidade Estadual Paulista "Júlio de Mesquita Filho", Faculdade de Engenharia de Ilha Solteira, Departamento de Fitotecnia, Tecnologia de Alimentos e Sócio Economia, Ilha Solteira, São Paulo, Brasil. arf@agr.feis.unesp.br

${ }^{4}$ Instituto Federal do Mato Grosso do Sul, Departamento de Ciências Agrárias, Nova Andradina, Mato Grosso do Sul, Brasil. flavio.kaneko@ifms.edu.br

${ }^{5}$ Universidade Estadual Paulista "Júlio de Mesquita Filho", Faculdade de Engenharia de Ilha Solteira, Departamento de Fitotecnia, Ilha Solteira, São Paulo, Brasil. flavia.meirelles1905@gmail.com

${ }^{6}$ Fundação Chapadão, Chapadão do Sul, Mato Grosso do Sul, Brasil. marceloarf@fundacaochapadao.com.br

*Corresponding author: michelletraete@ hotmail.com 
avaliações: cobertura vegetal residual (quantidade), características agronômicas, componentes de produção e produtividade da cultura do trigo. As culturas antecessoras apresentaram efeitos positivos na produtividade do trigo cultivado em sucessão, sendo o consórcio de milho e Urochloa ruziziensis, com ou sem inoculação excelente opção de manejo; o incremento da dose de $\mathrm{N}$, em cobertura, até $90 \mathrm{~kg} \mathrm{ha}^{-1}$ aumenta a produtividade de grãos de trigo irrigado, dependendo da cultura antecessora.

Palavras chave: Triticum aestivum L.; sistema plantio direto; Zea mays L.; Urochloa ruziziensis R. Germ \& Evrard; consórcio; Azospirillum brasilense.

\section{INTRODUCTION}

Wheat is very important in the agricultural production system of southern midwest region of Brazil as an economically viable alternative for crop rotation system, aiming to increase mainly the production of straw and grain yield in no-till systems, as well as reduction of pests and pathogens, among others (Piccinin et al., 2013).

Initially, the introduction of wheat in areas originally covered with vegetation of cerrado faced problems of cultivar adaptation. Thus, there is need for information on soil and water management for wheat production in these regions, providing increases in crop yield (Souza, 2003).

The no-till system is adopted for wheat production in Brazil, and knowledge on previous crop covers and their residual effects on succeeding crops is essential for a correct adoption of the system.

The numerous crop species previously cultivated provide variable residual effects, and the recommendation is the use of those with greater potential for increasing yield of economic crops (Aita et al., 2001), since the actual amount of nutrients used by the new crop will depend not only on the capacity of nutrient and cycling accumulation, as well as the timing between the decomposition of biomass and the period of higher demand by the new crop (Bredemeier \& Mundstock, 2001).

Nitrogen is an important nutrient for the crop and may be limiting for the growth of plants when not adequately supplied (Oliveira et al., 2005). However, a significant portion of the nitrogen applied as mineral fertilizer is lost through leaching, denitrification and volatilization. Thus, the major challenge in $\mathrm{N}$ management is to increase the amount absorbed by plants, and, at the same time, decrease the losses due to the complexity of soil and plant interactions (Nunes et al., 2011).

Previous crops play an important role in this interaction, and the management adopted can benefit the succeeding crop. Plant-growth-promoting bacteria can help, by different mechanisms, in nitrogen nutrition of crops (Sala et al., 2008). According to Alvarez et al. (1996), bacteria of the genus Azospirillum, besides being asymbiotic $\mathrm{N}_{2}$ fixing, are also considered plant growth-promoting rhizobacteria commonly associated with cereal roots, mainly grasses. Hungria et al. (2010) evaluated the inoculation of Azospirillum brasilense in wheat and maize and reported significant yield responses when compared with the noninoculated control.

There is currently an optimistic expectation in relation to the management of production systems; one of these forms of management is the association of Azospirillum brasilense with grasses (corn single crop and corn intercropped with Urochloa ruziziensis R. Germ \& Evrar) in the summer and off-season, in many regions of the Brazilian cerrado. Thus, the cover crop cultivation, preceding wheat irrigated by spraying may result in increased grain yield, enhancement of plant residues left on the soil surface (straw), which is fundamental to the sustainability of no tillage system in the long term and, hence, to reduce the costs of nitrogen fertilizer in the succeeding wheat crop.

In this context, the objective of this study was to evaluate the influence of the preceding crop, consisting of corn and Urochloa ruziziensis, and topdress nitrogen rates, on the development and grain yield of no-tillage wheat in a low-altitude cerrado region.

\section{MATERIAL AND METHODS}

\section{Experimental area}

This study was carried out in the Teaching and Research Farm of the Universidade Estadual Paulista "Julio de Mesquita Filho", located in Selvíria, MS, 51 22' W and $20^{\circ} 22^{\prime}$ S, $335 \mathrm{~m}$ altitude, in the 2011/12 agricultural year. The soil is classified as an Oxisol, epi-eutrophic Alic, clayey, according to Embrapa (2013). The area was originally occupied by cerrado vegetation and has been cultivated with annual crops for almost 30 years. The climate is defined as tropical humid with rainy season in summer and dry in winter (Aw), according to Köppen. The average annual temperature is around $25^{\circ} \mathrm{C}$, annual rainfall 
of $1.330 \mathrm{~mm}$, and average relative humidity of $66 \%$ (Centurion, 1982). Figure 1 shows 10-day rainfall values and maximum and minimum air temperature recorded during the wheat experimental period.

A composite soil sample was collected in the area, consisting of 20 sub-samples, taken from the 0.00 to $0.20 \mathrm{~m}$ layer and homogenized for chemical analysis, according to Raij et al. (1996), with the following results: $\mathrm{P}$ (resin) = $12 \mathrm{mg} \mathrm{dm}^{-3}$; organic matter $=15 \mathrm{~g} \mathrm{dm}^{-3} ; \mathrm{pH}\left(\mathrm{CaCl}_{2}\right)=5.1 ; \mathrm{K}$, $\mathrm{Ca}, \mathrm{Mg}, \mathrm{Al}$ and $\mathrm{H}+\mathrm{Al}=2.6 ; 26 ; 13 ; 1$ and $16 \mathrm{mmol}_{\mathrm{c}} \mathrm{dm}^{-3}$, respectively, and $\mathrm{S}=11 \mathrm{mg} \mathrm{dm}^{-3} ; \mathrm{V} \%=73$.

\section{Experimental design}

The experiment was arranged in a randomized block design. The treatments were arranged in a $8 \times 4$ factorial design, with four replications. The first factor consisted of eight treatments derived from the combination of previous cover crops, with or without seed inoculation with $A$. brasilense (corn; corn inoculated; U. ruziziensis; $U$. ruziziensis inoculated; corn $+U$ ruziziensis; corn inoculated $+U$. ruziziensis; corn + U. ruziziensis inoculated; corn inoculated $+U$. ruziziensis inoculated). The second factor consisted of four nitrogen rates $\left(0,30,60\right.$ and $\left.90 \mathrm{~kg} \mathrm{ha}^{-1}\right)$ topdressed to the wheat crop. The experimental plots consisted of six 5m-long rows. The harvested area for sample collection considered the four central rows of each plot, discarding $0.50 \mathrm{~m}$ from the end of each row.

\section{Experiment implementation and conduction}

Single corn was sown at a spacing of $0.90 \mathrm{~m}$ between rows and 5.4 plants per furrow meter. On the same date, single Urochloa ruziziensis was sown at $0.45 \mathrm{~m}$ between rows at a density of $20 \mathrm{~kg} \mathrm{ha}^{-1}$ of seeds. Urochloa ruziziensis intercropped with corn was sown in furrows between rows $0.45 \mathrm{~m}$ apart from corn rows at a density of $10 \mathrm{~kg} \mathrm{ha}^{-1}$ of seeds.

Sowing of corn hybrid AG 8088 PRO was held on November 3, 2011. Initial chemical fertilization in furrows used $300 \mathrm{~kg} \mathrm{ha}^{-1}$ of the formulation 04-30-10. Before sowing, corn and Urochloa seeds were inoculated with the Ab-V5 and Ab-V6 strains, in the shade, with $200 \mathrm{~g}$ of peat inoculant with $2 \times 108$ viable cells per gram of commercial product per $25 \mathrm{~kg}$ of seeds.

Sidedress application of $30 \mathrm{~kg} \mathrm{ha}^{-1} \mathrm{~N}$ in the form of ammonium sulfate was carried out at the V5 corn growth stage. Urochloa was not fertilized. After corn harvest, the cover crop was desiccated with glyphosate (1.920 a.i. g ha${ }^{1}$ ) and, three days after, mechanically mowed at the height of $0.10 \mathrm{~m}$ above the ground.

Wheat was sown on 08/05/2012 and irrigated by sprinkling. Cultivar IAC 373, with high potential for grain yield in both dryland farming conditions and irrigated by sprinkling, was mechanically sown with a no till seeder/ fertilizer drill, at the spacing of $0.17 \mathrm{~m}$ between rows and density of 400 viable seeds $\mathrm{m}^{-2}$.

Application of $250 \mathrm{~kg} \mathrm{ha}^{-1}$ basic fertilization to wheat was performed using the formula 04-30-10. Nitrogen was applied approximately at 25 DAE, using $0,30,60$ and $90 \mathrm{~kg}$ $\mathrm{ha}^{-1} \mathrm{~N}$, according to the treatments, distributed by hand alongside rows, using urea $(45 \% \mathrm{~N})$ as $\mathrm{N}$ source. After fertilization, the area was irrigated with $13 \mathrm{~mm}$ of water to

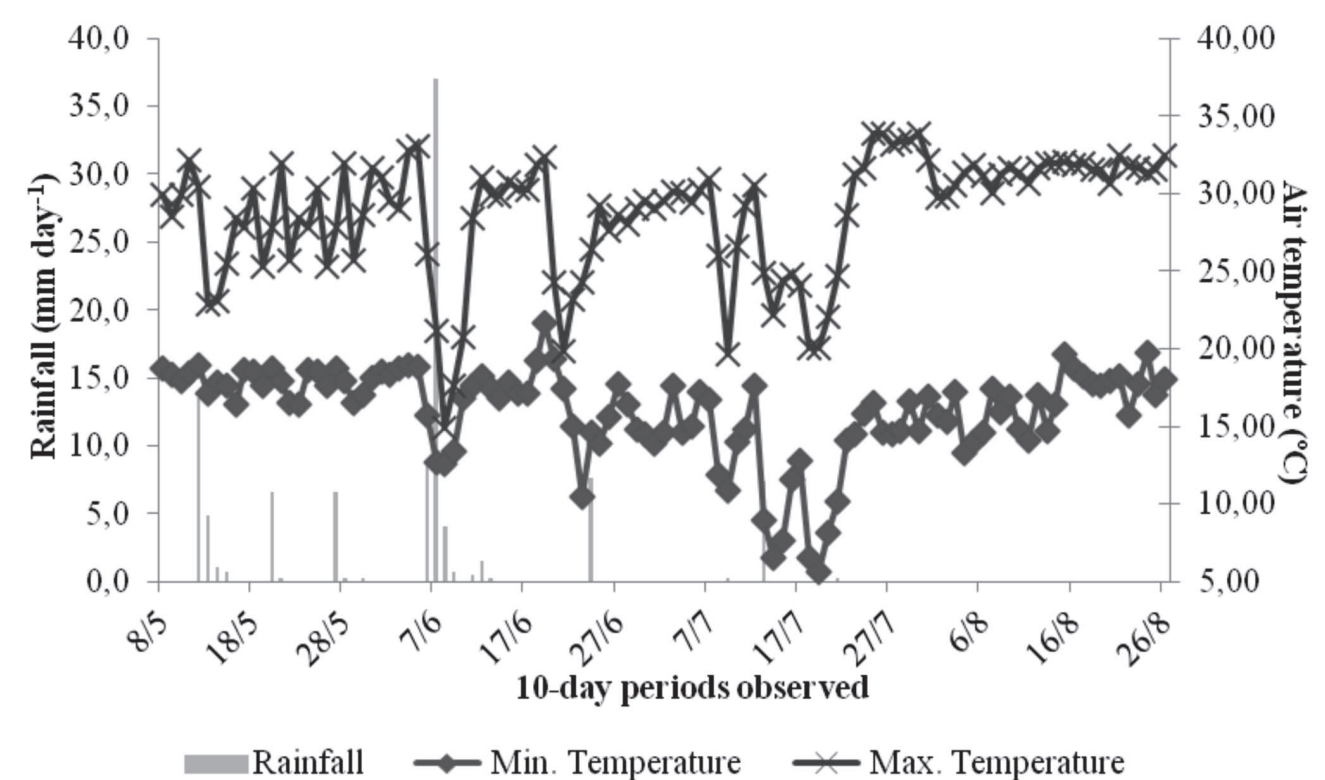

Source: Weather Station at the Hydraulics and Irrigation Laboratory FEIS - UNESP. Prepared by Sabundjian 2012.

Figure 1: Rainfall ( $\mathrm{mm} /$ day) and maximum and minimum temperature $\left({ }^{\circ} \mathrm{C}\right)$ obtained in the experimental area during the wheat growing season in Selvíria MS, 2012 agricultural year.

Rev. Ceres, Viçosa, v. 63, n.3, p. 394-402, mai/jun, 2016 
incorporate the fertilizer into the soil and avoid losses by volatilization

Broadleaf weed control was carried out with the postemergence herbicide metsulfurom methyl ( 3 a.i.g ha $\left.{ }^{-1}\right)$ at 9 DAE. During the dry season, the water was supplied to the crop by a center pivot irrigation system, with water depth of approximately $13 \mathrm{~mm}$ and 3-day irrigation interval.

\section{Agronomic evaluation}

Dry matter mass of previous cover crops was determined after mechanical mowing by collecting plant residues in a $0.25 \mathrm{~m}^{2}$ square at two points of each plot. The material was taken to the laboratory, dried in a forced air oven at $65^{\circ} \mathrm{C}$ to constant mass, quantified and extrapolated to $\mathrm{kg} \mathrm{ha}^{-1}$. Leaf nitrogen content was determined by collecting 20 flag leaf blades per plot during flowering, which, after drying, were ground in a Wiley mill and then digested by sulfuric acid, as described by Malavolta et al. (1997). Head number per $\mathrm{m}^{2}$ was determined at harvest by counting the number of heads at two points of 1-m row within the harvest area of each plot, and expressed as $\mathrm{m}^{2}$. Hectoliter mass was determined by weighing a $0.25 \mathrm{~L}$ wheat sample, adjusting the mass to $13 \%$ moisture and converting to $100 \mathrm{~kg} \mathrm{~L}^{-1}$. Grain yield was determined by collecting three 4-m central rows from the harvest area in the plots. The plants were harvested by hand and threshed mechanically, then the grain mass was determined and transformed to $\mathrm{kg} \mathrm{ha}^{-1}$ (13\% wet basis).

\section{Statistical analysis}

Data were examined by analysis of variance and $\mathrm{F}$ test. Means of cover crops were compared by the Tukey test at $5 \%$ probability. The effect of nitrogen rates was analyzed by polynomial regression. The analyses used the software SISVAR (Ferreira, 2007).

\section{RESULTS AND DISCUSSION}

Seedling emergence occurred uniformly for all treatments, on 13/05/2012, five days after sowing. Full flowering occurred at $50 \mathrm{DAE}$ and the crop had a total cycle of 108 days. During the experiment, there was no water restriction, lodging or plant health problems that could interfere with the development of plants.

\section{Dry mass of previous cover crops}

Table 1 shows significant differences between treatments, and those without intercropping had the largest amounts of straw in the treatments with Urochloa ruziziensis, mainly inoculated Urochloa ruziziensis, which produced more than $11.3 \mathrm{Mg} \mathrm{ha}^{-1}$ of plant residues on the soil surface, and both differed significantly from the corn treatments. Similarly, Reis Jr et al. (2004) found more bacterial associations in Urochloa species that were inoculated with Azospirillum in areas under pastures of the Atlantic Forest. In such work, the authors also confirmed the growth hormone production (IAA - indole acetic acid) for all Azospirillum isolates, relating this fact with the greatest accumulation of dry matter.

Table 1 also shows that the single corn inoculated with Azospirillum brasilense produced on average $25 \%$ more vegetation cover than the treatment without inoculation, which produced the least amount of vegetation. A similar result was obtained by Quadros (2009) studying the inoculation of Azospirillum spp. in seeds of corn genotypes grown in the Rio Grande do Sul, and found increased root volume in the evaluated cultivars and increased dry matter yield of shoots of corn plants inoculated with Azospirillum brasilense, which seems to be related to the increased photosynthetic activity. Similarly, Reis Jr et al. (2008) reported increased dry matter and nutrient accumulation by two corn genotypes inoculated with Azospirillum amazonense under different nitrogen rates.

In addition, according to Okon \& Vanderleyden (1997), the symbiosis between Azospirillum ssp and corn and between Azospirillum ssp and Urochloa would reduce production costs with nitrogen fertilizers and cause less environmental impact.

On the other hand, among the intercropping treatments, those without inoculation of corn and Urochloa with Azospirillum showed the highest production of vegetation cover $\left(10,422 \mathrm{~kg} \mathrm{ha}^{-1}\right)$. The other treatments had at least one of its components (corn or Urochloa) inoculated and separated by only $0.45 \mathrm{~m}$ between rows. Nobrega et al. (2004) discussed that the soil microbial community regulated by the environment and by substrate availability ensure different types of relationships (competitive, antagonistic, associative and symbiotic) between its components, which allows the control of growth and activity of each species, avoiding population explosion and promoting soil microbiological equilibrium.

Nunes et al. (2011) explained that studies on the influence of crop residue left on the soil surface in the yield of wheat in succession are relatively recent, which shows the importance of the results obtained in this study.

\section{$N$ leaf content}

The $\mathrm{N}$ content in wheat leaves at the beginning of silking were adequate, according to the nutritional standards recommended by Raij et al. (1996), considered to be between 20 and $34 \mathrm{~g} \mathrm{~kg}^{-1}$. There was interaction between vegetation cover and topdress nitrogen rates for leaf nitrogen content (Table 1).

The unfolding of the interaction between vegetation cover and nitrogen and its effect on leaf nitrogen content are shown in Table 2. The unfolding of the covers in the rates showed the influence of the vegetation cover in the absence of 
nitrogen fertilization and at the rate of $90 \mathrm{~kg} \mathrm{ha}^{-1} \mathrm{~N}$. In the absence of nitrogen fertilization, corn inoculated with Azospirillum had higher leaf nitrogen content than corn without inoculation and Urochloa with inoculation. This increase may be associated with the effect the bacteria promote on root growth of plants, caused by the induction of growth-promoting substances such as auxin and cytokinin (Okon \& Labandera-Gonzalez, 1994).

Hungria et al. (2011) argued that diazotrophs, besides providing the supply of nitrogen to inoculated plants, may stimulate growth and accumulation of dry matter mass, benefiting crops in succession. However, when the rate of topdress $\mathrm{N}$ was $90 \mathrm{~kg} \mathrm{ha}^{-1}$, the leaf nitrogen content was higher in the treatment where the previous crop was noninoculated corn, which was higher than the corn inoculated, than the intercroppings corn + Urochloa without inoculation, corn + Urochloa inoculated and corn inoculated + Urochloa inoculated. This result is because nitrogen is a very dynamic nutrient in the soil and plant residues, and the use of topdressed $\mathrm{N}$ was not optimized due to losses through leaching and volatilization, making the inoculation with diazotrophs very important for mineral nutrition and preservation of natural resources.

As for the unfolding of nitrogen rates in the vegetation cover, it was found that in the treatments where the previous crop was corn, Urochloa, Urochloa inoculated and the intercropping corn inoculated + Urochloa, the results for leaf nitrogen fitted to an increasing linear function. On the other hand, Teixeira Filho et al. (2008), evaluating the agronomic performance of wheat cultivars in response to plant population and nitrogen fertilizer, reported that the leaf $\mathrm{N}$ content fitted to a quadratic function in relation to $\mathrm{N}$ rates, with the point of maximum $\mathrm{N}$ content achieved with the application of $100 \mathrm{~kg} \mathrm{ha}^{-1} \mathrm{~N}$. The results of this study agree with those of Teixeira Filho et al. (2010), who reported the influence of $\mathrm{N}$ rates on $\mathrm{N}$ leaf content of wheat, obtaining linear fits in 2006 and quadratic fits in 2007 , with point of maximum estimated content with the application of $163 \mathrm{~kg} \mathrm{ha}^{-1}$ of $\mathrm{N}$. Despite the positive responses of leaf $\mathrm{N}$ content to nitrogen fertilization, the study was conducted in an irrigated area, which helped in better fertilizer utilization and subsequently in the incorporation of this nutrient into plants. After $\mathrm{N}$ application, irrigation was performed with a water lamina to incorporate the nitrogen source applied (urea) because of some limitations on its efficiency.

\section{Head number per square meter}

There was interaction between vegetation cover and topdress nitrogen rates for the wheat head number (Table 1 ). The unfolding of the interaction between vegetation covers and nitrogen and its effect on the head number are shown in Table 3. Analysis of the unfolding of covers in the rates shows the influence of vegetation cover in all

Table 1: Average values of production components and yield of wheat grown on different cover crops and nitrogen rates in no-tillage

\begin{tabular}{|c|c|c|c|c|c|}
\hline Treatments & Dry M. (kg ha $\left.{ }^{-1}\right)$ & Leaf $N\left(\mathrm{~g} \mathrm{~kg}^{-1}\right)$ & Heads $\left(\mathrm{m}^{-2}\right)$ & HectoliterM. (kg) & Yield $\left(\mathrm{kg} \mathrm{ha}^{-1}\right)$ \\
\hline \multicolumn{6}{|l|}{ Cover crop (C) } \\
\hline Corn & $7,459 \mathrm{e}$ & 40.95 & 415.44 & 83.77 & 3,507 \\
\hline Corn Inoculated (I) & $9,289 \mathrm{~cd}$ & 40.54 & 437.87 & 83.71 & 3,593 \\
\hline Urochloa & $10,884 \mathrm{ab}$ & 39.53 & 357.35 & 84.36 & 3,243 \\
\hline Urochloa Inoculated (I) & $11,272 \mathrm{a}$ & 39.43 & 386.76 & 84.13 & 3,185 \\
\hline Corn + Urochloa & $10,422 \mathrm{abc}$ & 40.07 & 373.90 & 83.12 & 3,728 \\
\hline Corn $(\mathrm{I})+$ Urochloa & 9,654 bcd & 42.01 & 354.04 & 83.17 & 3,526 \\
\hline Corn + Urochloa $(\mathrm{I})$ & $9,140 \mathrm{~cd}$ & 40.45 & 330.52 & 84.19 & 3,477 \\
\hline Corn (I) + Urochloa (I) & $8,691 \mathrm{de}$ & 40.16 & 384.19 & 83.57 & 3,319 \\
\hline \multicolumn{6}{|l|}{ N Rates $\left(\mathrm{kg} \mathrm{ha}^{-1}\right)$ (D) } \\
\hline 0 & & 37.95 & 334.56 & 83.26 & 2,954 \\
\hline 30 & & 39.18 & 359.38 & 84.05 & 3,290 \\
\hline 60 & & 41.27 & 403.13 & 84.10 & 3,663 \\
\hline 90 & & 43.02 & 422.98 & 83.60 & 3,881 \\
\hline $\mathrm{C}$ & $16.63^{*}$ & $2.12^{*}$ & $7.50^{* *}$ & $1.73^{\mathrm{ns}}$ & $3.07^{* *}$ \\
\hline F Test D & & $32.01^{* *}$ & $20.45^{* *}$ & $2.62^{\mathrm{ns}}$ & $30.38^{* *}$ \\
\hline $\mathrm{CxD}$ & & $4.93^{* *}$ & $3.38^{* *}$ & $1.50^{\mathrm{ns}}$ & $2.69^{* *}$ \\
\hline LSD C & $1,448.10$ & 2.49 & 55.28 & 1.54 & 461 \\
\hline$\overline{\mathrm{CV}(\%)}$ & 6.36 & 5.63 & 13.27 & 1.67 & 12.19 \\
\hline
\end{tabular}

**, * and ${ }^{\mathrm{ns}}$ - significant at 1 and $5 \%$ probability by the $\mathrm{F}$ test and non-significant, respectively;

Means followed by the same letter are not significantly different by the Tukey test at $5 \%$ probability;

LSD - least significant difference by the Tukey test.

Rev. Ceres, Viçosa, v. 63, n.3, p. 394-402, mai/jun, 2016 
topdress $\mathrm{N}$ rates. When the wheat did not receive topdress $\mathrm{N}$, the best result was obtained when the previous crop was corn inoculated, which was statistically different from treatments cultivated on corn straw intercropped with Urochloa, except for the treatment corn inoculated + Urochloa witthout inoculation.

Topdress of $30 \mathrm{~kg} \mathrm{ha}^{-1}$ nitrogen resulted that the treatments with the smallest ear numbers per $\mathrm{m}^{2}$ were those managed on straw of Urochloa without inoculation, corn + Urochloa inoculated, and corn inoculated + Urochloa inoculated. However, at the rate $60 \mathrm{~kg} \mathrm{ha}^{-1}$ nitrogen, the treatments that differed from the others, with the lowest head numbers per $\mathrm{m}^{2}$, were intercropped in the same way as the previous rate, but this time, those with corn inoculated + Urochloa without inoculation and corn without inoculation + Urochloa inoculated had the lowest means.

Topdress of $90 \mathrm{~kg} \mathrm{ha}^{-1} \mathrm{~N}$ showed same trend as topdress of $60 \mathrm{~kg} \mathrm{ha}^{-1} \mathrm{~N}$, and the smallest head numbers per $\mathrm{m}^{2}$ were obtained in treatments with Urochloa with or without inoculation (Table 3). Zagonel et al. (2002) discussed that all wheat production components can benefit to a greater or lesser extent from nitrogen, except the plant population. Wheat has the characteristic of filling in gaps in the crop by producing tillers with fertile heads, making up for possible sowing problems.

The unfolding of nitrogen rates in the vegetation cover (Table 3) showed that in the treatments with the previous crops corn, corn inoculated, corn inoculated + Urochloa inoculated or corn non-inoculated + Urochloa noninoculated occurred a linear increase with topdress $\mathrm{N}$ rates, and that the effect of these previous covers combined with supply of $90 \mathrm{~kg} \mathrm{ha}^{-1} \mathrm{~N}$ met the demand of wheat for the production of heads per $\mathrm{m}^{2}$. Moreover, the presence of
Azospirillum in the soil along the wheat cycle is important for a better competition with native microorganisms, which are less efficient in colonization and biological fixation of nutrients in grasses.

However, additional nitrogen inputs have great importance for the photosynthesis, thanks to the considerable increase in pigments responsible for capturing solar energy through the thylakoid (Taiz \& Zeiger, 2004).

Cazetta et al. (2007) studied the response of wheat and triticale cultivars to nitrogen in no-tillage. They observed that, in relation to topdressing nitrogen, the data fitted to a quadratic equation, in the 2004 harvest year, regardless the cultivar, with plants reaching the largest number of culms with $79.2 \mathrm{~kg} \mathrm{ha}^{-1} \mathrm{~N}$, and the largest number of heads with $75.7 \mathrm{~kg} \mathrm{ha}^{-1} \mathrm{~N}$.

Teixeira Filho et al. (2010) evaluated rates, sources and times of application of nitrogen in no-till irrigated wheat. They found that the $\mathrm{N}$ rates positively influenced the number of heads per $\mathrm{m}^{2}$ in 2007, and, fitted to a quadratic function, had the maximum value achieved with the estimate of $113 \mathrm{~kg} \mathrm{ha}^{-1} \mathrm{~N}$.

In this study, despite the treatments not having showed statistical differences for the variable hectoliter mass, all values were above 78 , which adds greater value to the cereal at the time of marketing (Table 1).

\section{Wheat grain yield}

There was interaction between cover crops and topdress nitrogen rates for grain yield (Table 1). The unfolding of the interaction between cover crops and nitrogen rates and its effect on grain yield is shown in Table 4. The unfolding of the cover crops in the $\mathrm{N}$ rates showed that without the nitrogen fertilizer, the treatment with Urochloa without

Table 2: Leaf nitrogen content of wheat grown on different cover crops and nitrogen rates in no-tillage

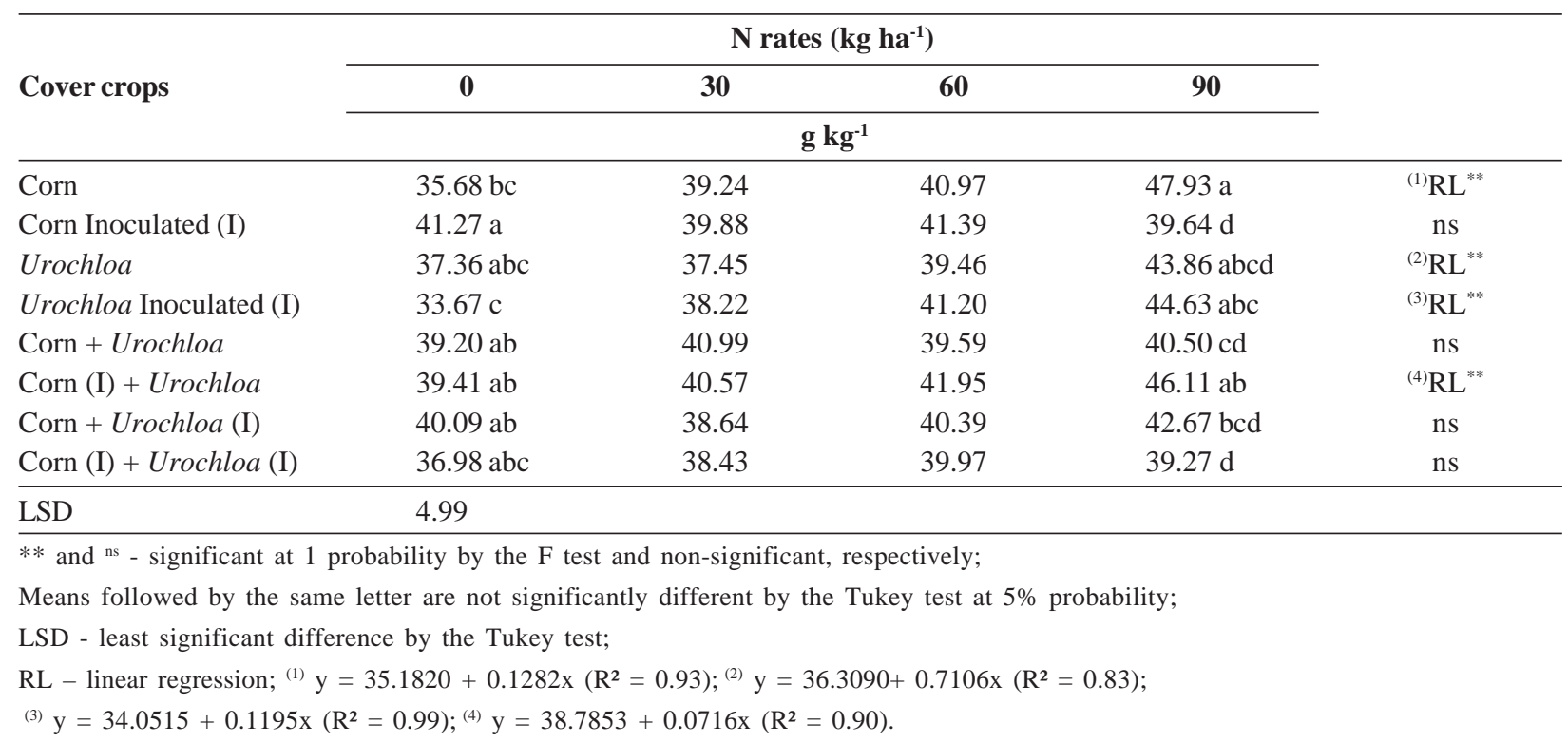


inoculation was inferior to the intercroppings corn without inoculation + Urochloa without inoculation and corn inoculated + Urochloa without inoculation of Azospirillum brasilense. These treatments produced about $50 \%$ more (18 sacks of wheat), which points out the importance of the crop that preceded the wheat.

Topdress of $30 \mathrm{~kg} \mathrm{ha}^{-1} \mathrm{~N}$ to the treatment of corn inoculated with Azospirillum brasilense increased significantly wheat yield (17 sacks of wheat), corresponding to $38 \%$ more in the increase of yield than that of Urochloa with and without inoculation. There were no statistical differences for the rates of 60 and $90 \mathrm{~kg} \mathrm{ha}^{-1}$ $\mathrm{N}$ in the treatments with the different cover crops.
The unfolding of nitrogen rates in the cover crops showed a linear increase with topdress $\mathrm{N}$ application to the treatments with corn (increase of 36\% - 18 sacks), Urochloa (88\% - 33 sacks), Urochloa inoculated (60\% - 26 sacks) and corn non-inoculated + Urochloa non-inoculated (21\% - 12 sacks). These increases represent gains in yield and decrease in the use of mineral fertilizer, if integrated properly with the choice of the previous crops to provide good input of dry matter mass and at the same time not compromise the establishment of succeeding crops. The excess plant material might cause some problems related to the good establishment of succeeding plants due to the difficulty in straw-cutting operations and the correct

Table 3: Number of heads per $\mathrm{m}^{2}$ of wheat cultivated on different vegetation cover crops and nitrogen rates in no-tillage

\begin{tabular}{|c|c|c|c|c|c|}
\hline \multirow{3}{*}{ Cover crops } & \multicolumn{4}{|c|}{$\mathrm{N}$ rates $\left(\mathrm{kg} \mathrm{ha}^{-1}\right)$} & \\
\hline & $\mathbf{0}$ & 30 & 60 & 90 & \\
\hline & \multicolumn{4}{|c|}{$\mathbf{m}^{-2}$} & \\
\hline Corn & $327.94 \mathrm{ab}$ & $440.30 \mathrm{a}$ & $450.18 \mathrm{ab}$ & $457.32 \mathrm{ab}$ & ${ }^{(1)} \mathrm{RL}^{* *}$ \\
\hline Corn Inoculated (I) & $426.47 \mathrm{a}$ & $437.06 \mathrm{ab}$ & $458.83 \mathrm{ab}$ & $544.12 \mathrm{a}$ & ${ }^{(2)} \mathrm{RL}^{* *}$ \\
\hline Urochloa & $329.41 \mathrm{ab}$ & $329.41 \mathrm{~b}$ & $383.82 \mathrm{abc}$ & $386.77 \mathrm{bc}$ & ns \\
\hline Urochloa Inoculated (I) & $358.83 \mathrm{ab}$ & $385.29 \mathrm{ab}$ & $391.18 \mathrm{abc}$ & $411.77 \mathrm{bc}$ & $\mathrm{ns}$ \\
\hline Corn + Urochloa & $279.41 \mathrm{~b}$ & $386.77 \mathrm{ab}$ & $392.65 \mathrm{abc}$ & $436.76 \mathrm{abc}$ & ${ }^{(3)} \mathrm{RL}^{* *}$ \\
\hline Corn $(\mathrm{I})+$ Urochloa & $332.35 \mathrm{ab}$ & $363.24 \mathrm{ab}$ & $352.94 \mathrm{bc}$ & $367.65 \mathrm{bc}$ & ns \\
\hline Corn + Urochloa $(\mathrm{I})$ & $313.24 \mathrm{~b}$ & $333.82 \mathrm{~b}$ & $344.12 \mathrm{c}$ & $330.88 \mathrm{c}$ & ns \\
\hline Corn $(\mathrm{I})+$ Urochloa $(\mathrm{I})$ & $308.82 \mathrm{~b}$ & $329.12 \mathrm{~b}$ & $465.30 \mathrm{a}$ & $468.53 \mathrm{ab}$ & ${ }^{(4)} \mathrm{RL}^{* *}$ \\
\hline $\operatorname{LSD}(5 \%)$ & 110.57 & & & & \\
\hline \multicolumn{6}{|c|}{ ** and ${ }^{\mathrm{ns}}$ - significant at 1 probability by the $\mathrm{F}$ test and non-significant, respectively; } \\
\hline \multirow{2}{*}{\multicolumn{6}{|c|}{$\begin{array}{l}\text { Means followed by the same letter are not significantly different by the Tukey test at } 5 \% \text { probability; } \\
\text { LSD - least significant difference by the Tukey test. }\end{array}$}} \\
\hline & & & & & \\
\hline \multicolumn{6}{|c|}{$\mathrm{RL}-$ linear regression; ${ }^{(1)} \mathrm{y}=323.8248+1.1470 \mathrm{x}\left(\mathrm{R}^{2}=0.70\right) ;{ }^{(2)} \mathrm{y}=364.4110+1.6323 \mathrm{x}\left(\mathrm{R}^{2}=0.70\right)$} \\
\hline
\end{tabular}

Table 4: Grain yield of wheat cultivated on different cover crops and nitrogen rates in no-tillage

\begin{tabular}{|c|c|c|c|c|c|}
\hline \multirow{3}{*}{ Cover crops } & \multicolumn{4}{|c|}{$\mathrm{N}$ rates $\left(\mathrm{kg} \mathrm{ha}^{-1}\right)$} & \\
\hline & $\mathbf{0}$ & 30 & 60 & 90 & \\
\hline & \multicolumn{4}{|c|}{$\mathrm{kg} \mathrm{ha}^{-1}$} & \\
\hline Corn & $2.914 \mathrm{ab}$ & $3.541 \mathrm{abc}$ & 3.571 & 4.003 & ${ }^{(1)} \mathrm{RL}^{* *}$ \\
\hline Corn Inoculated (I) & $3.052 \mathrm{ab}$ & $3.690 \mathrm{a}$ & 4.053 & 3.814 & ${ }^{(2)} \mathrm{RQ}^{* *}$ \\
\hline Urochloa & $2.270 \mathrm{~b}$ & $2.658 \mathrm{c}$ & 3.765 & 4.278 & ${ }^{(3)} \mathrm{RL}^{* *}$ \\
\hline Urochloa Inoculated (I) & $2.570 \mathrm{ab}$ & $2.752 \mathrm{bc}$ & 3.289 & 4.128 & ${ }^{(4)} \mathrm{RL}^{* *}$ \\
\hline Corn + Urochloa & $3.421 \mathrm{a}$ & $3.446 a b c$ & 3.896 & 4.147 & ${ }^{(5)} \mathrm{RL}^{* *}$ \\
\hline Corn $(\mathrm{I})+$ Urochloa & $3.340 \mathrm{a}$ & $3.596 \mathrm{ab}$ & 3.365 & 3.802 & ns \\
\hline Corn + Urochloa $(\mathrm{I})$ & $3.108 \mathrm{ab}$ & $3.215 \mathrm{abc}$ & 3.221 & 3.465 & ns \\
\hline Corn $(\mathrm{I})+\operatorname{Urochloa}(\mathrm{I})$ & $2.958 \mathrm{ab}$ & $3.521 \mathrm{ab}$ & 3.346 & 3.453 & ns \\
\hline
\end{tabular}

** and ${ }^{\mathrm{ns}}$ - significant at 1 probability by the $\mathrm{F}$ test and non-significant, respectively;

Means followed by the same letter are not significantly different by the Tukey test at $5 \%$ probability;

LSD - least significant difference by the Tukey test.;

$\mathrm{RL}$ - linear regression; $\mathrm{RQ}$ - quadratic regression; ${ }^{(1)} \mathrm{y}=3012.9107+10.9845 \mathrm{x}\left(\mathrm{R}^{2}=0.90\right)$;

(2) $\mathrm{y}=3023.9184+34.2940 \mathrm{x}-0.3092 \mathrm{x}^{2}\left(\mathrm{R}^{2}=0.97\right) ;{ }^{(3)} \mathrm{y}=2173.3436+23.7661 \mathrm{x}\left(\mathrm{R}^{2}=0.97\right)$;

(4) $\mathrm{y}=2403.4992+17.3659 \mathrm{x}\left(\mathrm{R}^{2}=0.93\right) ;{ }^{(5)} \mathrm{y}=3333.5023+8.7559 \mathrm{x}\left(\mathrm{R}^{2}=0.92\right)$.

Rev. Ceres, Viçosa, v. 63, n.3, p. 394-402, mai/jun, 2016 
deposition of seed in the ground, allowing appropriate conditions for germination.

Nunes et al. (2011) reported that the yield of no-till wheat was influenced by two factors studied (green manures and topdress nitrogen rates), with significant interaction between them. These authors pointed out that among the evaluations, the nitrogen content in wheat leaves and the number of seeds per head were the best indicators of how topdress nitrogen fertilization and green manures influenced significantly in achieving greater wheat yield.

Similarly, Cazetta et al. (2007), studying the response of wheat and triticale cultivars to nitrogen in the no-tillage system, found that nitrogen fertilization promotes positive yield increments up to $78 \mathrm{~kg} \mathrm{ha}^{-1}$. They also suggest that the grain yields obtained over two harvest years, in a lowaltitude tropical region, enable the conclusion that irrigated wheat is a possible alternative for winter crop rotation.

However, the results obtained in the treatment with corn inoculated had quadratic effect, reaching the maximum at 55 $\mathrm{kg} \mathrm{ha}^{-1}$ topdressed nitrogen, which represents an increase of $60 \%$ in the production, resulting in 30 wheat sacks for marketing. Likewise, Teixeira Filho et al. (2007), studying the response of four wheat cultivars (IAC 24, IAC 364, IAC 370 and IAC 373) to different topdress $\mathrm{N}$ rates $(0,30,60,90$ and $\left.120 \mathrm{~kg} \mathrm{ha}^{-1}\right)$ in the form of urea, with sprinkler irrigation in the Cerrado region, found that the $\mathrm{N}$ rates influenced significantly the grain yield in a quadratic way.

The other cover crops showed no effects of nitrogen rates (Table 4). Teixeira Filho et al. (2010) also reported that the $\mathrm{N}$ rates influenced the wheat yield in the two years of cultivation, and fitted to quadratic functions with maximum yield achieved with $121 \mathrm{~kg} \mathrm{ha}^{-1}$ of N. Our results are in accordance with the findings of Piccinin et al. (2013) that reinforce the fact that inoculation with Azospirillum brasilense should always be associated with the nitrogen fertilization, which can favor the agronomic characteristics of wheat, contributing with additional inputs to yield. Adding to these facts, the findings of Braccini et al. (2012) confirm the hypothesis that inoculation of strains Ab-V5 and Ab-V6 of Azospirillum brasilense becomes an efficient management strategy for wheat, in order to decrease the use of nitrogen fertilizer, contribute to environment improvement, and enable the reduction of nitrogen fertilizer application on wheat by $50 \%$, thereby reducing input and labor costs.

According to Lamothe (1998), although it is possible to increase each component individually, compensatory phenomena often cause the components to be related, with the tendency of increasing some and decreasing others; thus, the same yield can be achieved in different ways, making it difficult to establish an optimum combination of components.

\section{CONCLUSIONS}

Wheat had increased yield when grown in succession to corn intercropped with Urochloa ruziziensis, both inoculated with Azospirillum brasilense, in the summer.

The increase in topdress nitrogen rate up to $90 \mathrm{~kg} \mathrm{ha}^{-1}$ provides grain yield increase in irrigated wheat using the Urochloa ruziziensis, single corn and corn + Urochloa as preceding vegetation cover.

\section{ACKNOWLEDGEMENTS}

The authors thank the staff at FEPE - UNESP and Capes for the scholarship awarded to the student Michelle Traete Sabundjian during the experimental period.

\section{REFERENCES}

Aita C, Basso CJ, Ceretta CA, Gonçalves CN \& Da Rós CO (2001) Plantas de cobertura do solo como fonte de nitrogênio ao milho. Revista Brasileira de Ciência do Solo, 25:157-165.

Alvarez MI, Sueldo RJ \& Barassi CA (1996) Effect of Azospirillum on coleoptile growth in wheat seedlings underwater stress. Cereal Research Communications, 24:101-107.

Braccini AL, Dan LGM, Piccinin GG, Albrecht LP, Barbosa MC \& Ortiz AHT (2012) Seed inoculation with Azospirillum brasilense, associated with theuse of bioregulators in maize. Revista Caatinga, 25:2898-2903.

Bredemeier C \& Mundstock CM (2001) Estádios fenológicos do trigo para a adubação nitrogenada em cobertura. Revista Brasileira de Ciência do Solo, 25:317-323.

Cazetta DA, Fornasieri D \& Arf O (2007) Resposta de cultivares de trigo e triticale ao nitrogênio no sistema de plantio direto. Científica, 35:155-165.

Centurion JF (1982) Balanço hídrico da região de Ilha Solteira. Revista Científica, 10:57-61.

Embrapa - Empresa Brasileira de Pesquisa Agropecuária (2013) Sistema brasileiro de classificação de solos. $3^{\text {a }}$ ed. Brasilia, Embrapa. 353p.

Hungria M, Campo RJ, Souza EM \& Pedrosa FO (2010) Inoculation with selected strains of Azospirillum brasilense and A. lipoferum improves yields of maize and wheat in Brazil. Plant and Soil, 331:413-425.

Hungria M (2011) Inoculação com Azospirillum brasilense: inovação em rendimento a baixo custo. Londrina, Embrapa Soja. 36p.

Lamothe AG (1998) Fertilización con N y potencial de rendimiento en trigo. In: Kohli MM \& Martino DL (Eds.) Explorando altos rendimientos de trigo. Montevideo, CIMMYT/INIA. p.207246.

Malavolta E, Vitti GC \& Oliveira AS (1997) Avaliação do Estado Nutricional das Plantas: princípios e aplicações. $2^{\mathrm{a}}$ ed. Piracicaba, Potafos. 319p.

Nobrega RSA, Moreira FMS, Siqueira JO \& Lima AS (2004) Caracterização fenotípica e diversidade de bactérias diazotróficas associativas isoladas de solos em reabilitação após a mineração de bauxita. Revista Brasileira do Solo, 2:269-279.

Nunes AS, Souza LCF \& Mercante FM (2011) Adubos verdes e adubação mineral nitrogenada em cobertura na cultura do trigo em plantio direto. Bragantia, 70:432-438. 
Okon Y \& Labandera-Gonzalez CA (1994) Agronomic applications of Azospirillum: an evaluation of 20 years worldwide field inoculation. Soil Biology and Biochemistry, 26:1591-1601.

Okon Y \& Vanderleyden J (1997) Root-associated Azospirillum species can stimulate plants. ASM News, 63:364-370.

Oliveira IP, Costa KAP, Rodrigues C, Macedo FR, Moreira FP \& Santos KJG (2005) Manutenção e correção da fertilidade do solo para inserção do cerrado no processo produtivo. Revista Eletrônica Faculdade Montes Belos, 1:50-64.

Piccinin GG, Braccini AL, Dan LGM, Bazo GL, Hossa KR \& Ponce RM (2013) Rendimento e desempenho agronômico da cultura do trigo em manejo com Azospirillum brasilense. Revista Agrarian, 6:393-401

Quadros PD (2009) Inoculação de Azospirillum spp. em sementes de genótipos de milho cultivados no Rio Grande do Sul. Dissertação de Mestrado. Universidade Federal do Rio Grande do Sul, Porto Alegre. 62p.

Raij B, Cantarella H, Quaggio JÁ \& Furlani AMC (1996) Recomendações de adubação e calagem para o Estado de São Paulo. $2^{\mathrm{a}}$ ed. Campinas, Instituto Agronômico. 285p. (Boletim Técnico, 100).

Reis Júnior FB, Silva MF, Teixeira KRS, Urquiaga S \& Reis VM (2004) Identificação de isolados de Azospirillum amazonense associados a Brachiaria spp., em diferentes épocas e condições de cultivo e produção de fitormônio pela bactéria. Revista Brasileira de Ciência do Solo, 28:103-113.

Reis Junior FB, Machado CTT, Machado AT \& Sodek L (2008) Inoculação de Azospirillum amazonense em dois genótipos de milho sob diferentes regimes de nitrogênio. Revista Brasileira de Ciência do solo, 32:1139-1146.
Sala VMR, Cardoso EJBN, de Freitasm JG \& da Silveira APD (2008) Interaction of new diazotrophic endophytic bacteria and nitrogen fertilization on wheat crop under field conditions. Revista Brasileira de Ciências do Solo, 32:1099-1106

Souza RAR (2003) Comportamento de cultivares de arroz de terras altas em função do preparo do solo e irrigação por aspersão, em latossolo vermelho de cerrado. Dissertação de Mestrado. Universidade Estadual Paulista, Ilha Solteira. 68p.

Taiz L \& Zeiger E (2004) Fisiologia vegetal. $3^{\text {a }}$ ed. Porto Alegre, Artmed. 613p.

Teixeira Filho MCM, Buzetti S, Alvarez RCF, Freitas JG, Arf O \& Sá ME (2008) Desempenho agronômico de cultivares de trigo em resposta a população de plantas e a adubação nitrogenada. Científica, 36:97-106.

Teixeira Filho MCM, Buzetti S, Alvarez RCF, Freitas JG, Arf O \& Sá ME (2007) Resposta de cultivares de trigo irrigados por aspersão ao nitrogênio em cobertura na região do Cerrado. Acta Scientiarum. Agronomy, 29:421-425.

Teixeira Filho MCM, Buzetti S, Andreotti M, Arf O \& Benett CGS (2010) Doses, fontes e épocas de aplicação de nitrogênio em trigo irrigado em plantio direto. Pesquisa Agropecuária Brasileira, 45:797-804.

Zagonel J, Venancio WS, Kunz RP \& Tanamati H (2002) Doses de $\mathrm{N}$ e densidades de plantas com e sem um regulador de crescimento afetando trigo cultivar OR-1. Ciência Rural, 32:25-29. 